\title{
Deterioration of Indonesian Language in the Age of Globalization
}

\author{
St. Sahriati \\ Maritime Academy Veteran Republic of Indonesia (AMI) Makassar \\ Doi:10.5296/jsr.v5i2.6334 \\ URL: http://dx.doi.org/10.5296/jsr.v5i2.6334
}

\begin{abstract}
Indonesian language is one of languages in the world affected by globalization. The larger vocabularies we have from loan words of foreign language and technological advances, and then language, people and culture of Indonesia recognized by citizen of the world, as well as developing linguistic style of literary work in Indonesian are some examples of positive effects of globalization. Conversely, linguistic hierarchy has emerged linguistic stigmatization and lack of contextual linguistic consciousness, and the role of Indonesian as a unifying tool and identity of Indonesia has also faded away. This condition shall be taken into consideration by linguistic strategy, for example, by making use of hegemonic foreign language within the function limits of communication and by avoiding formation of ideological construction which can be done by suspending an agreement. In the such way, it will be able to construct people of polyphonic language user.
\end{abstract}

Keywords: Globalization, Language, Indonesia

\section{Introduction}

Globalization is interpreted that borders of among nations become narrower as the consequence of globalized economy and massive economic impact. Just like an analogy of the rolling snowball, it does not affect in just small quantity. Social, knowledge, technology, culture and religion systems cannot escape from this globalization effect, so does language system.

Orientation of global economy which travels through space and time makes the need of communication much more higher. Language proficiency in addition to local and national languages becomes an absolute necessity. Various study programs at colleges and courses which lectures foreign language and increasing number of interested people in foreign classes are one of proofs that people today considers foreign language proficiency as a need (and necessity). Besides, today, some companies are looking for labors who mention pre-requirement of proficiency in one of foreign languages (commonly English), either in written or oral.

Even, some job vacancy ads of companies in national mass media are advertised in foreign language (English). Similar with other developing countries, globalization affects particularly language, with no exception in Indonesia. The larger vocabularies, Indonesian language 
recognized by citizen of the world and the more well known of produced literary works are some positive effect of globalization. Otherwise, globalization issues linguistic hierarchy and falls linguistic consciousness down in society.

This article will discuss some emerged linguistic problems as the consequence of globalization along with linguistic strategy which may be applied to obstruct marginalization threat of Indonesian language in the age of globalization.

\section{Hegemony of Language in Global Society}

Language and society are two inseparable things; not only playing role as means of communication, but, language is also inseparable from shades of political ideology. The success of Western hegemony in various countries may be used as an example like what had been happened in Turkey when national policy on education in 1928 removed Arabic and Persian subject in schools. Moreover, the Latin alphabet was set as style of writing which replaced Arabic writing, and religion subject in village and urban schools was gradually removed. Likewise in India, this condition becomes one of another examples on how Western world demonstrates their hegemony to language. In India, English which nota bene the language of imperialist is, exactly, set as national language. Even, English language and literature is compulsory subject in schools. Spivak in Huda (2004) makes a note relating to this matter (Huda, 2004). He judges that English language learning compulsorily in schools is a kind of epistemic violence. Dealing with this matter, he suggests people to use the language of imperialist in context with linguistic mechanism only.

On the other hand, in connection with ideological construction or thought forming, he suggests reader to suspend an agreement to avoid formation of colonial subject. So does Said (2003) whose suggestion during an interview was published as a book by Gauri Viswanathan untitled Kekuasaan, Politik, and Kebudayaan. Said (2003) believes that colonial often utilizes language as a means of power legitimacy over the colonized, especially due to economic motive. In a school based in Egypt, it is frankly announced that English is spoken language in the school. Punishment will be given to those who break the rule, for example when pupil speaks in local language (Arabic) in conversation. This condition makes egotistical of the colonized maintained; in spite of their proficiency of language, literature and knowledge on English are good, it will not change themselves into English men. Other linguistic problem which emerges in the age of globalization is linguistic stigmatization. Singh (2007) gives an example of linguistic stigmatization occurred in California in 1998 when Spanish teaching banning is set for Hispanic. Linguistic stigmatization also strikes Punjab people living in England.

Foreign language proficiency elevates personal social class compared to native speaker. There is still local dialect in communication may make personal social status low (Jones, 2007). Income factor is one of causal factor on why people are encouraged to become proficient at foreign language in global era (Thornborrow, 2007). It is understandable since in general, international companies invest or broaden their business where human resources and natural resources have lower price, and these can be found in developing countries. Therefore, foreign language proficiency is necessity (and obligation today).

This phenomenon is experienced by countries worldwide, especially in developing countries. 
Foreign language proficiency becomes demand or obligation. Sometimes, what is emerging is denial on native or national language, exclusively or elusively. Process of being part of globalization, sometimes, also erodes national identity which is commonly unified by race, history, or language (Cavallaro, 2004; Anderson, 2002).

\section{The Impact of Globalization on Indonesian Language}

The influence of globalization on Indonesian language is seen at Indonesian vocabularies when Indonesian language is more acknowledged by other citizens of the world, and the greater amount of literature written by Indonesian writers. Vocabulary development in Indonesian language, indeed, indicates a sufficient rapid development. According to Abdul Gaffar Ruskan, one of researcher in the Language Center, Ministry of National Education, at present, the amount of vocabularies in the Great Dictionary of the Indonesian Language (Kamus Besar Bahasa Indonesia of KBBI) of IV edition reach approximately one hundred thousand vocabularies. In addition to loan word from foreign language, vocabularies also increase due to language standardization from local language into Indonesian language. If it is observed closely in the Great Dictionary of the Indonesian Language of III edition, it adopts more from Javanese language compared to other local languages. It is seen, for example, in page 1288-1289 which consists of local words and idioms. Javanese language dominates more in the pages, and then Sundanese, Minangkabau, Balinese, Sasak and Madurese languages. Intention presence to standardize vocabularies from other local languages, for example Dayak and other local languages, for future IV edition shall be welcomed positively as an effort to preserve local language. Technological advance is one of causal factors which broaden vocabularies amongst our people. Today, people are almost acquainted with terminologies about computer, mobile phone, SMS, email, download or homepage. Some terminologies are present due to the presence of technological advance terminologies in Indonesian language. For example, email become "surat elektronik". SMS (Short Message Service) in Indonesian is "pesan singkat", or homepage is translated into "laman", while download become "mengunduh". However, sometimes people prefer using foreign term to looking for an exact translation in Indonesian for some motives of practicability, meaning accuracy, or just a prestige. Finally, globalization compels a nation to arrange strategy in order not only to witness globalization, but also to have an important role in the process of it.

Around 1930s, when a book entitled Belenggu was published, in fact, Armin Pane got a note relating to many Ducth terminologies he used in the book. Along with attitude of Japanese colonizer in 1940s who tends to be more permissive by giving chance to speak in Indonesian, literary work born during the time use Indonesian more, although Dutch terminologies use could be still found. Poems written by Chairil Anwar may, presumably, become examples on how Indonesian linguistic style at that time are lifelike and more expressive. So does the novel entitled Atheis by Achdiat K. Mihardja. Unstable condition in Indonesia, especially in 1965 s, produces literary works in realist-prone linguistic style, away from "flowery" impression. This style is maintained until 1970s. Open contiguity to the outside world during Soeharto leadership affects Indonesia, including literature field.

In literary works written by Iwan Simatupang or Budi Darma, what judged continually were 
absurdity of Camus and Sartre, or mini-word theater by Rendra in which people say that the works were affected by Godot when he has just learned about drama in the US (Soemanto, 2002). In 1980, Indonesian literati are close by local atmosphere. This is marked by setting of the story which takes place in local setting (in spite of urban or Jakarta City), and the use of local language lexicon in the works. Famous literati using this style in their works are Darmanto Jatman, Gunawan Muhammad, Linus Suryadi AG, YB Mangunwijaya, and Umar Kayam; most of them are from Java. Hamsad Rangkuti and AA Navis are literati from Sumatra and they are famous because of local atmosphere in their works. In the late 1900, since the opening of reformation age in 1998, literary works were born close by reality. Storytelling and linguistic styles tend to be as the writer wants to, open, and sometimes it breaks taboo value at a time before. The name of Ayu Utami, presumably, cannot be ignored as writer name who tends to write as she wants to. Journalistic style represented by Seno Gumira Ajidarma, i.e. when reader reads his book, he experiences a sense of reading news in newspaper since Ajidarma presents a fact written in literary language which can make the reader dizzy due to some metaphor and parable the writer used. However, globalization will never give positive effect only. Negative side of globalization to linguistic problem is marked by linguistic hierarchy and diminishing of linguistic consciousness contextually. It is undeniable that fast movement of the flows of globalization have made numbers of people think hard to avoid of being marginal people (peripheral, marginal) who have minimum role and even become the victims.

This pragmatic state is apparently responded fast by some education organizers, either in formal or non formal level. Today, almost every university has foreign languages and literature course. The most favorite programs of study for foreign language are English, German, French, Japanese and Arabic. In addition to establishing the program of study, some universities also establish program of study for foreign language, such as Korean and Mandarin Chinese. Foreign language courses are more easily to be found. Pragmatic orientation in dealing with job market seems undeniable. At least, foreign language proficiency will allow job seekers to pass requirement demanded by job-seeking company. As conveyed by Thornborrow (2007), foreign language proficiency in global era is pragmatic attitude in order to earn more income. Such condition is more likely found in Indonesian people. Thus, it is to say that globalization has an effect on the presence of linguistic hierarchy. In fact, linguistic hierarchy in Indonesia does not even appear lately.

Even, it had appeared since colonialism era in Indonesia. During the Dutch colonialism in this country, Dutch language becomes the most prestige language amongst Indonesian people. It was only a very small number of people, i.e. elite noblemen, who were able to master and learn Dutch language. Even though, those our elite people and noblemen were mastering Dutch language, they were not same. One of advantages of mastering Dutch language learned by indigeneous people is literary access which finally works into literacy. Literacy awakens national consciousness on those elite people. Development of literacy culture allows them to interact with outside community and strengthens their socio-cultural and politic-ideology comprehension which is worth for future development on national ideas.

Most of Indonesian educated men and politicians went to European style education. At that moment, Malay language were second language amongst our community. It was also 
triggered by colonial-politic of the Dutch that Malay language were divided into two, Chinese-Malay and Javanese-Malay. However, Salmone (1985) believes that Chinese-Malay were not actually exist, so what present afterwards was Javanese-Malay spoken by ethnic Javanese, Dutch and Chinese. Yet, it was still Dutch language in the highest class amongst Indonesian people at that time. In 1940s, when Japan colonized Indonesia, condition of our language were slightly changed. Dutch language which long time ago dominated our language were finally had less learning intensity. This change was driven by Japanese government policy which banned Dutch language learning, and the government allowed us to not only being cramped by language, but also the culture. Sastro Darsono in his novel entitled Para Priyayi were annoyed of being forced to salute the sun every morning and being forced to sing national anthem of Japan.

Post independence day of Indonesia, it could be said that the use of Indonesian language was better. Even, during period of the New Order, government were sophisticated to utilize Indonesian language as the means of dominating, legitimating and preserving the power by conducting many linguistic euphemism. The word of "being secured", for example, was a kind of arrest euphemism to those who were considered as people having power to shake power of the New Order. Since article on the practice of Indonesian language euphemism for political needs have been discussed a lot by some researchers or linguists, this article will not discuss the matter further. Simply matter for capitalism to instill the power in Indonesia is, for example, by foreign investment policy which is widely opened for foreign company in the New Order government. This policy becomes initial entrance of foreign language legitimacy-hegemony in Indonesia. Thenceforth, foreign language learning, especially English, are commonly found in schools. In this reformation era, foreign language teaching may be found in the world of education, from kindergarten to senior high school. Even, some private schools (commonly labeled as "national or international standard") teach foreign language, not only English, but also Mandarin Chinese, Arabic, French, Korean or Japanese for the choices. The objective definitely is no other than preparing graduates who have multi language proficiencies, so they will not be nervous of facing the world.

Disadvantageous condition of language in this global era is, indeed, faced by local language. It is not all schools provide sufficient portion for local language teaching. Some schools provide local language as Local Content subject for the pupils at limited class hours. Local language teaching is schools definitely shall be complemented with a number of treatments. Rosidi (1983) suggests that in order to boost local language interest, it shall be complemented with infrastructure, media and local language teachers. To preserve the use of local language amongst community, Rosidi (1983) suggests the government to prepare labors possessing well local speaking communication. It seems that the fact in field is rather different. Media Indonesia newspaper on February 18th, 2008 conducted research on the use of local language in six metropolis in Indonesia, i.e. Makassar, Surabaya, Yogyakarta, Bandung, Jakarta and Medan, covering 480 adult respondents which had been randomly chosen from telephone book. Research quotation as stated in this www.mediaindonesia.com hopefully will depict position of local languages in Indonesia in global era:

Local language lies in the lowest level of linguistic hegemony happened today. The first rank, obviously is given to foreign languages, and the followed by Indonesian language. In spite of 
many devotee of foreign language study program, training center or course, there are some facts recently that Indonesian people has a paradigm if foreign language is above Indonesian language. Media is one of media which has sufficient effect amongst community. Today, people have already understood that an ads is advertised in foreign language (English) Confession on foreign language advantage had ever been displayed openly by private educational institution by advertising that "English + Math = success". The ads indirectly shows that foreign language proficiency (English) is more important since it can guarantee the success.

Media becomes an effective means to affect the mass and to build ideological construction. Besides, media utilization is able to be a reflection on speaking consciousness of Indonesian people. Today, television audience are entertained by motion pictures of celebrities, politicians, elite-officials, informal leaders in which code switching-mixing is easily and commonly used and with no intention, even it is used for prestige only. Issue of code mixing or code switching is an ordinary matter in the practice of communication. The code does not have an intention to satisfy prestige of certain social class only. Or maybe, the practice has moved to that intention recently, that those who are able to speak in foreign language, or at least, say it a little in daily conversation indicates higher social class. Someone, who accidentally appears in media with certain local dialect, in fact, becomes joke. Misye Arsita in Ketoprak Humor often become the victim of joke because her Indonesian speaking is thick of regional dialect or Javanese dialect. When Nadine Chandrawinata makes a mistake by naming Indonesian as city, despite of country, public are hilariously leaving comments, one of them is impropriety of Indonesian representative in international level having language mistake. Such linguistic stigmatization is excessively found in community. There has been existed an attitude of humiliating native language or local language. Unluckily, indication of stigmatization to national language begins to appear. In fact, if community has consciousness on the context and the role of Indonesian language, indeed, stigmatization will not happen.

\section{Linguistic Strategy in the Global Era}

Recent practice of linguistic hierarchy-hegemony and also linguistic stigmatization need specific strategy in order not to make native or national speakers left behind in mastering foreign language, and a strategy which is able to make national or local language everlasting. English language hegemony cases in Turkey, India and Egypt and also some other colonized countries, presumably, were a lesson for all of us that globalization (colonialism-capitalism) may become a threat and opportunity, all at once, for development of a language. Foreign language use within the function limits of mechanism of communication, but it is not for ideological construction which bears epistemic violence, may be applied. Literary or cultural teaching on the learned society shall be made as foundation for polyphonic character building (Cavallaro, 2004).

Afterward, this polyphonic character will create personalities who possess awareness and tolerance of diversity. In spite of building polyphonic character, literary or cultural learning shall be in balance with critical awareness through a number of interpretation which may 
suspend agreement to ideological construction proposed by authority. Polyphonic character building strategy which does not fall into epistemic violence may be applied in formal level. The presence of foreign language to be learned and survived in global era is a necessity, but national and local language keeping is not less important. Language Day or Language Corner are examples of linguistic strategy which is applicable in formal level. Language Day is time and day schedule when a language shall be used. Determined language is Language Day should cover foreign and local languages as well as national or Indonesian language, and these languages have to be used proportionally. Language Corner in an informal environment may be still applied in formal schools, society and within a family. How precise an strategy is, if it is not backed up by great linguistic consciousness, it will not achieve an ideal linguistic environment in the society. Therefore, government departments like Education Department (Elementary, Junior High or Senior High Schools), Language Center and other departments has quite great role to invite Indonesian people to love and protect Indonesian language as unitary and identity language of Indonesia nation.

An identity may be connected to race, history and language similarities. Identity has been reflected in the Youth Pledge declared by Indonesian youths who are completely aware of their Indonesian identity in one motherland, one nation and one language of Indonesian. Some actual actions to invite people to love Indonesian language had been taken by society, private institution and also government institution. Sympathetic invitation to love and use Indonesian language is positive step conducted by Indonesian people who are aware of the importance of Indonesian language preservation-use. Commemoration on Language Month, Book Day, the Youth Pledge Day, annual commemoration of the death of Chairil Anwar or other commemorations are effective momentum to campaign the use of Indonesian language in general occasion relating to the context and function.

\section{Conclusion}

a. Globalization is a certainty, so does its impact on life, including language. Indonesian language is one of languages in the world which had also been affected by globalization.

b. Increasing number of vocabularies and developing society also affect linguistic style of literary work in Indonesia. However, globalization will not always affect positively.

c. Supposing that consciousness on Indonesian language use and appreciation as unitary and identity language is not improved, participation of society, government and private institutions in formal and non formal level shall be elevated to face the problem.

d. Some strategies may be given to face linguistic problems existing in global era. First, restriction on the use of foreign language. Second, suspend ideological construction agreement offered by literary or cultural discourse by conducting critical interpretation on it. 
References

Anderson, B. 2002. Imagined Communities . Yogyakarta: Insist \& Pustaka Pelajar.

Cavallaro, D. 2004. Critical and Cultural Theory. Yogyakarta: Sufi Books.

Huda, N. 2004. Dismantling Violence in the epistemic" Hermeneutika Pascakolonial: Soal Identitas. Yogyakarta: Kanisius.

Jones, J. 2007. Language and Social Class "in Language, Power, and Society.. Yogyakarta: Pustaka Pelajar.

Rosidi, A. 1983. Regional Language Development "in Development Interests Read, Language, and Literature. Surabaya: Bina Ilmu.

Salmone, C. 1985. Descendants of Chinese Literature in Malay. Jakarta: Pustaka Pelajar.

Singh, S. 2007. Language and Representation "in Language, Power, and Society. Yogyakarta: Pustaka Pelajar.

Soemanto, B. 2002. Godot in America and Indonesia: A Comparative Study. Jakarta: Grasindo.

Thornborrow, J. 2007. "Language and the media" in Language, Power, and Society. Yogyakarta: Pustaka Pelajar.

Viswanathan, G (ed). 2003. Power, Politics, and Culture: Interviews with Edward Said. Yogyakatra: Library Promothea. Source: "Regional Languages in Central Imminent Extinction". 